\title{
Program Kreativitas Mahasiswa Kewirausahaan Cheewings
}

\author{
Kamiliya Eka Putri ${ }^{1}$, Shazrin Daniyah Khansa ${ }^{1 *}$, Rizka Herlina ${ }^{1}$, Dini Safitri ${ }^{1}$ \\ ${ }^{1}$ Program Studi Ilmu Komunikasi Universitas Negeri Jakarta, Jalan Rawamangun Muka, Jakarta Timur, \\ Indonesia, 13220 \\ *Email Korespondensi: shazrindaniyah_ikom19s1@mahasiswa.unj.ac.id
}

\begin{abstract}
Abstrak
Perkembangan dunia kuliner saat ini menuntut kita untuk berpikir secara kreatif dalam menghasilkan sebuah produk baru. Karena hal tersebut, maka inovasi sangat dibutuhkan. Tujuan dari PKM Kewirausahaan cheeWings ini adalah untuk berkontribusi meningkatkan kekreativitasan serta untuk memotivasi masyarakat untuk selalu berinovasi di bidang kewirausahaan di era yang semakin maju ini. Program Kreativitas Mahasiswa ini kami jalankan dengan cara membagikan sepuluh buah produk kepada keluarga dan orang sekitar. Hasil yang kami peroleh cukup baik, mereka berkomentar bahwa produk ini sudah cukup baik dari segi rasa.
\end{abstract}

Kata kunci: Inovasi, produk, kreatif, makanan.

\begin{abstract}
The development of the culinary world today requires us to think creatively in producing a new product. Because of this, innovation is needed. The aim of the cheeWings Entrepreneurship Student Creativity Program is to contribute to increasing creativity and to motivate people to always innovate in the field of entrepreneurship in this increasingly advanced era. We run this Student Creativity Program by distributing ten products to families and people around us. The results we got were quite good, they commented that this product was good enough in terms of taste.
\end{abstract}

Keywords: Innovation, product, creative, food.

Format Sitasi: Putri, K.E., Khansa, S.D., Herlina, R. \& Safitri, D. (2020). Program Kreativitas Mahasiswa Kewirausahaan Cheewings. Jurnal Solma, 09(2), 444-451. Doi: http://dx.doi.org/10.22236/solma.v9i2.5177

Diterima: 26 Juni 2020 | Revisi: 03 September 2020 | Dipublikasikan: 30 Oktober 2020

(C) 2020 Oleh authors. Lisensi Jurnal Solma, LPPM-Uhamka, Jakarta. Artikel ini bersifat open access yang didistribusikan di bawah syarat dan ketentuan Creative Commons Attribution (CC BY) license. (http://creativecommons.org/licenses/by/4.0/).

\section{PENDAHULUAN}

Wirausaha merupakan gabungan kata dari "wira" dan "usaha". Wira artinya berani, utama, perkasa. Usaha artinya kegiatan dengan mengerahkan tenaga, pikiran, fisik demi tercapai suatu tujuan tertentu. Wirausaha ialah suatu kemampuan memanfaatkan, mencari, dan menciptakan peluang untuk mendapatkan yang diinginkan (Rusydi \& Rafida, 2016). Adapun manfaat wirausaha adalah sebagai berikut : bertambahnya tenaga kerja yang dapat ditampung, sebagai alat untuk membangun lingkungan, sebagai contoh untuk masyarakat lain, membantu orang lain, memelihara keserasian lingkungan (Rusdiana, 2014). 
Orang-orang yang menjadi wirausahawan adalah orang-orang yang tahu akan potensi dan belajar untuk mengembangkan peluangnya. Kewirausahaan memerlukan kekreativitasan dan juga inovasi. Jiwa kewirausahaan termasuk juga dalam kepribadian yang kreatif sebagai nilai, suka berjuang, kuat dalam menghadapi tantangan, kepercayaan diri, dan karakter yang telah tertanam menjadi nilai-nilai yang dipercaya kebenarannya (Kuratko, 2003). Perilaku wirausaha menunjukkan kemampuan wirausaha untuk selalu melihat ke depan, berpikir dengan perhitungan, mencari pilihan dari beberapa alternatif masalah dan solusinya (Suseno, 2008). Kita harus bisa melihat peluang yang ada (Saragih, 2017).

Untuk pembentukan manusia yang memiliki sikap, perilaku, dan jiwa wirausaha, pendidikan kewirausahaan harus dimulai pada tahun-tahun awal pembentukan manusia dan juga harus diperluas dengan kegiatan kewirausahaan dirumah dan di masyarakat yang lebih luas (Shalahuddin et al., 2018). Sebagai calon penerus bangsa, mahasiswa harus memiliki pengetahuan kewirausahaan agar dapat menumbuhkan jiwa usaha untuk berwirausaha. Minat dan pengetahuan mahasiswa tentang kewirausahaan diharapkan dapat membentuk kecenderungan untuk membuka bisnis baru di masa depan (Rosmiati et al., 2019).

Pada umumnya sesuatu yang unik dan berbeda merupakan hal yang selalu diinginkan oleh masyarakat, begitu pula dalam hal kuliner atau makanan. Oleh sebab itu, kami menciptakan cheeWings dengan harapan lebih banyak konsumen yang tertarik untuk mengonsumsi sayap ayam. Kami memilih sayap ayam karena sayap ayam memiliki cita rasa gurih, lebih lezat dan lebih manis daripada again ayam lainnya (Soechan, 2014). Daging ayam merupakan salah satu bahan makanan yang mengandung protein dari hewan yang baik karena mengandung asam amino esensialnya mengandung vitamin serta mineral penting (Susanto, 2006). Ayam juga memiliki beberapa manfaat, seperti protein, vitamin B-6, vitamin B-1, vitamin B-2, vitamin B-12, serta niacin yang sangat diperlukan bagi kesehatan saraf dan pertumbuhan (Murtidjo, 2003). Dalam memilih ayam yang segar dapat dilihat ciricirinya seperti berikut ini (Pradata, 2008) :

1. Daging yang masih kenyal dan tidak lembek.

2. Daging ayam tidak berbau amis atau busuk.

3. Daging akan langsung berubah seperti bentuk awal setelah ditekan.

4. Daging ayam tidak berwarna hitam kemerahan atau lebam.

5. Pada bagian tubuh ayam tidak terdapat bekas luka.

6. Kulit daging ayam berwarna kuning pudar atau putih.

Dalam pemilihan daging ayam yang segar pada bagian sayap, hal berikut ini yang perlu diperhatikan (Pradata \& Ika Ariestya, 2010) :

1. Bau tidak menyengat.

2. Daging tidak memar.

3. Daging masih melekat pada tulang dengan baik.

4. Kulit pada sayap masih segar, tidak layu, dan tidak berlendir.

Produk cheewings ini adalah sayap ayam diolah dengan cara dipanggang dan disajikan dalam bentuk yang cukup menarik, yaitu sayap ayam yang ditusuk seperti sate. Strategi pemasaran yang kami lakukan adalah dengan cara mempromosikan produk melalui instagram dengan username @ cheewings.id, selain itu kami juga memberikan harga promosi untuk pelanggan tertentu yang memenuhi persyaratan kami. Dengan mempertahankan 
kualitas dan rasa, kami yakin bahwa masyarakat akan menyukai produk sayap ayam ini. Terutama bagi masyarakat yang suka mengonsumsi ayam bagian sayap yang memiliki banyak manfaat.

Tujuan dari PKM Kewirausahaan cheeWings ini adalah untuk berkontribusi meningkatkan kekreativitasan serta untuk memotivasi masyarakat agar selalu berinovasi di bidang kewirausahaan supaya dapat bersaing dan di era yang semakin maju ini, sesuai dengan fungsi pemberdayaan masyarakat, yaitu dapat terjadinya peningkatan ekonomi mandiri terutama dalam bidang pendapatan masyarakat dan produktivitas (Kurniawati, 2013). Target dari PKM Kewirausahaan cheeWings ini adalah masyarakat sekitar lingkungan tempat tinggal penulis dan keluarga penulis.

Manfaat dari PKM Kewirausahaan cheeWings ini adalah untuk meningkatkan minat dan pemikiran masyarakat agar selalu berinovasi untuk mengembangkan produk. Salah satunya hal yang dapat dipelajari dari produk kami dalam berinovasi adalah menyajikannya secara unik dan beda dari yang lain supaya menarik.

\section{MASALAH}

Pada zaman sekarang sudah banyak sekali berbagai macam makanan yang dijual di pasaran, khususnya makanan yang berasal dari daging ayam. Selain itu di pasaran juga terdapat berbagai macam makanan dari olahan daging ayam dengan harga yang beragam, serta sudah beragam produk yang berdiri lebih dahulu sehingga sudah memiliki nama atau cukup dikenal di masyarakat. Beberapa hal tersebut merupakan tantangan dari produk kami, mengingat produk kami adalah produk baru.

\section{METODE PELAKSANAAN}

Dalam mengkonsumsi suatu produk, yang dilihat oleh konsumen tidak hanya pada nilai atau fungsi dari produk yang dibutuhkan, tetapi konsumen juga akan memperhatikan kelebihan serta nilai tambah yang dimiliki oleh suatu produk dengan produk sejenis yang lain (Rahmadi et al., 2016). Mengetahui bahwa cheeWings merupakan produk baru, maka terdapat tantangan untuk menjalankan kegiatan ini. Untuk menangangi tantangan ini maka dibutuhkan inovasi dalam melaksanakan dan membentuk cheeWings. Menurut Robbins, (1994); Sukmadi (2016) inovasi adalah suatu ide baru yang bertujuan supaya terdapat peningkatan mutu pada produk, jasa atau suatu proses. Dengan kata lain, inovasi adalah mememukan ide atau modifikasi untuk melakukan perbaikan untuk memenuhi kebutuhan masyarakat.

Inovasi yang dilakukan adalah cara penyajian dari produk cheeWings, yaitu sayap ayam cheeWings akan disajikan dengan cara dipanggang dan ditusuk seperti sate, serta menggunakan beberapa pilihan rasa seperti barbeque, bolognese, dan sambal matah yang menambah kelezatan dari sayap ayam cheeWings. Kami memutuskan untuk menggunakan sayap ayam karena sumber utama yang baik dari protein hewani berasal dari daging ayam. Asam amino yang terdapat pada daging ayam memiliki kandungan yang lengkap, serta mengandung vitamin dan mineral yang penting dan dibutuhkan untuk kesehatan. Di sisi lain, daging ayam juga mempunyai tekstur yang lebih lunak dan lebih halus daripada daging sapi dan daging sejenis unggas yang lainnya, sehingga lebih mudah agar tercerna di dalam tubuh 
(Murtidjo, 2003). Kami melakukan inovasi dengan cara seperti ini melihat di pasaran bahwa belum ada yang menyajikan sayap ayam seperti produk cheeWings.

Sebelum kegiatan dilaksanakan, kami mengenalkan produk melalui sosial media Instagram. Selain mengenalkan produk, kami juga mengedukasi manfaat dari daging ayam bagi kesehatan. Tujuannya agar masyarakat tertarik dan timbul rasa penasaran bagi masyarakat akan produk yang kami buat. Setelah beberapa minggu, kami memutuskan untuk membagikan sepuluh produk kepada orang-orang terdekat.

Dalam kegiatan ini kami membagikan produk sate sayap ayam cheeWings sebanyak 10 porsi kepada keluarga kami dan beberapa masyarakat di lingkungan tempat tinggal kami. Setelah membagikan produk, kami mendapatkan respon yang cukup baik dari orang-orang yang telah kami bagikan.

Fokus utama dari kegiatan ini adalah untuk membangkitkan minat masyarakat terhadap sayap ayam. Setelah mencoba mencicipi sate sayap ayam yang kami bagikan, para konsumen tahu bahwa sayap ayam sangat banyak manfaatnya serta dapat diolah dengan berbagai macam cara salah satunya adalah sate sayap ayam.

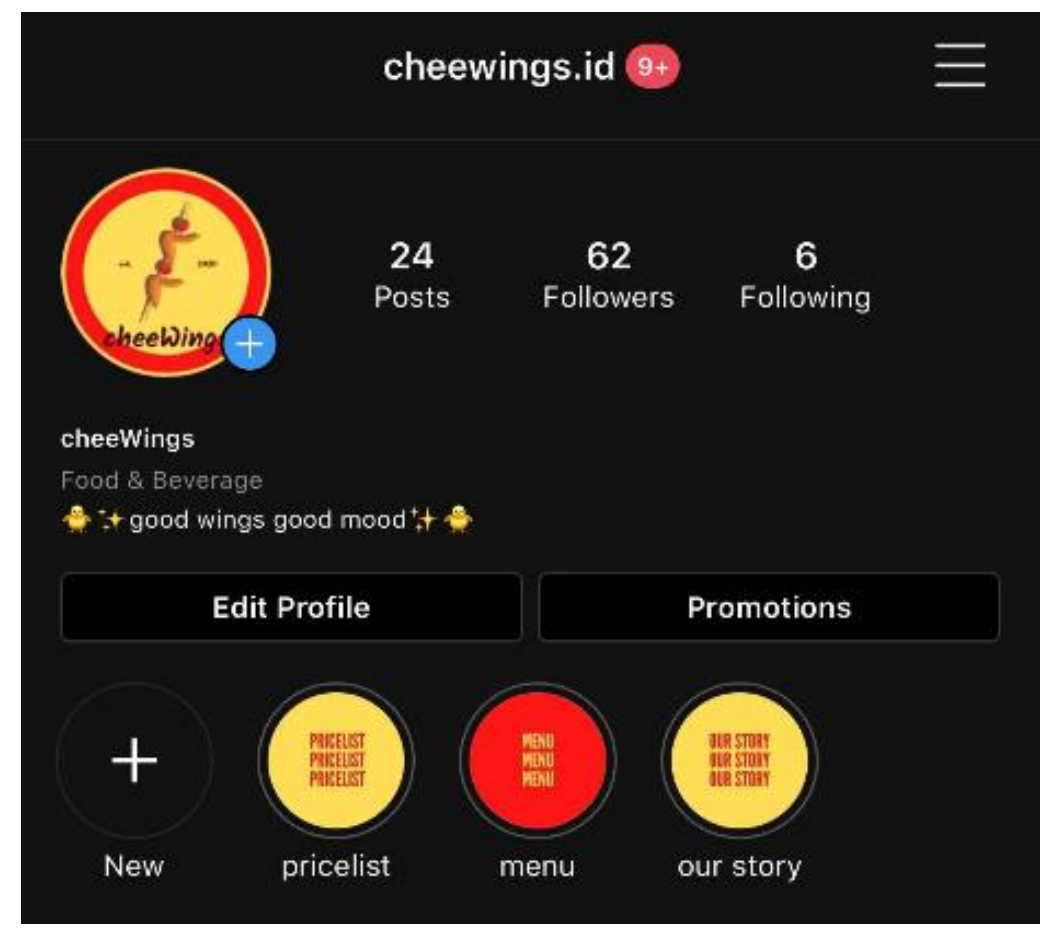

Gambar 1. Sosial Media Instagram cheewings 

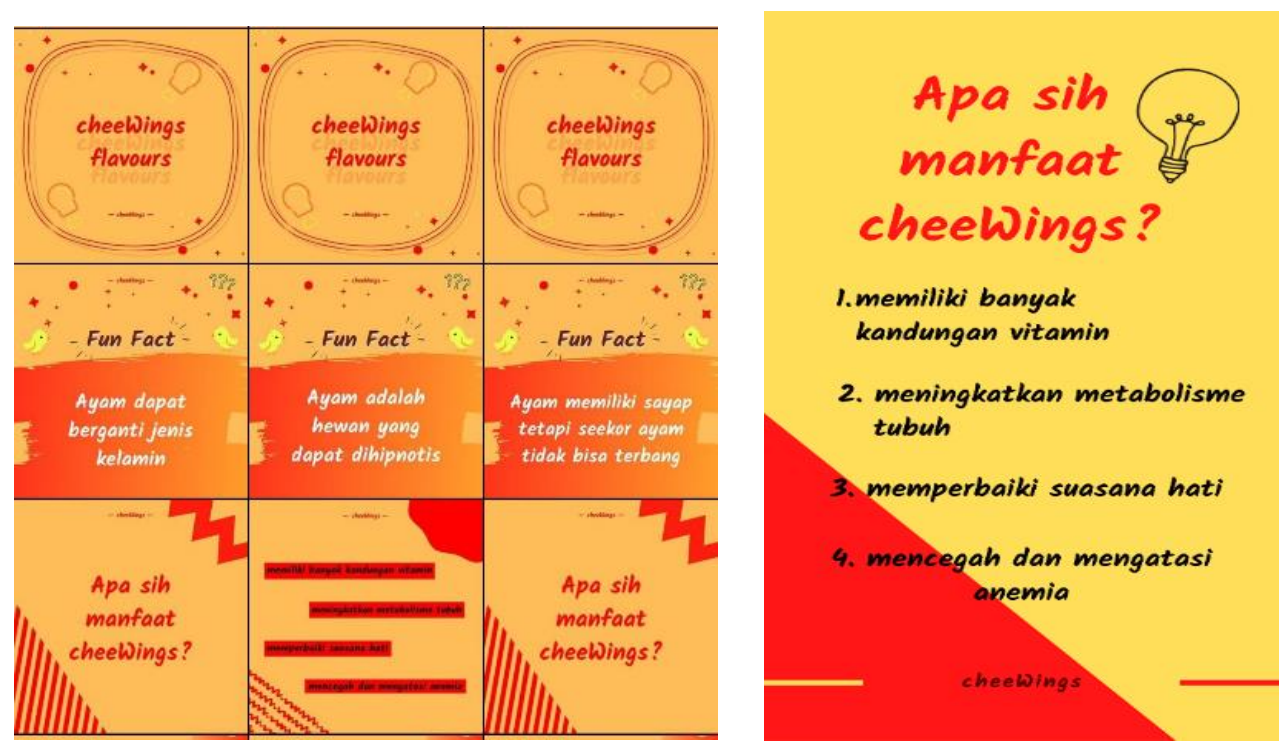

Gambar 2. Flayer via media sosial cheewings

\section{HASIL DAN PEMBAHASAN}

Dengan adanya kegiatan ini kami mendapatkan respon yang cukup baik dari orang orang yang telah kami berikan dan bersedia untuk mencoba produk sate sayap ayam kami. Kami juga mensosialisasikan dan memberi informasi tentang manfaat dari daging ayam dan pentingnya kesehatan bagi tubuh. Selain itu kami juga mendapatkan beberapa masukan untuk mendukung kemajuan dari produk yang akan kami jual tersebut.

Peserta yang terlibat dalam kegiatan ini sebanyak 21 orang. Peserta tersebut berasal dari univeristas negeri dan univeristas swasta. Berikut tabel peserta serta responden yang mengikuti kegiatan yang diadakan oleh "cheeWings".

Tabel 1. Asal Instansi Peserta cheeWings

\begin{tabular}{cc}
\hline Instansi & Jumlah Peserta \\
\hline Universitas Negeri Jakarta & 5 \\
Akademik Pariwisata Indonesia & 1 \\
Universitas Muslim Indonesia & 1 \\
Universitas Pendidikan Indonesia & 1 \\
Univeristas Bina Nusantara & 2 \\
Universitas Gunadarma & 2 \\
Universitas Diponegoro & 1 \\
UPN Veteran Jakarta & 2 \\
Universitas Prof. Dr. Moestopo & 1 \\
Poltekkes Jakarta 3 & 1 \\
Universitas Pakuan & 1 \\
IPMI International Business School & 1 \\
Universitas Singaperbang & 1 \\
Univeristas Trisakti & 1 \\
Jumlah & $\mathbf{2 1}$ \\
\hline
\end{tabular}


Tabel 2. Hasil Kuesioner

\begin{tabular}{|c|c|c|}
\hline Pertanyaan & Jawaban & $\begin{array}{l}\text { Jumlah } \\
\text { Pemilih }\end{array}$ \\
\hline $\begin{array}{l}\text { Apakah anda pernah memiliki usaha dibidang } \\
\text { kuliner? }\end{array}$ & $\mathrm{Ya}$ & 10 \\
\hline $\begin{array}{l}\text { Apakah anda pernah memiliki usaha kuliner } \\
\text { dengan bahan dasar ayam? }\end{array}$ & Tidak & 19 \\
\hline Apakah anda tahu apa saja manfaat sayap ayam? & $\mathrm{Ya}$ & 11 \\
\hline $\begin{array}{l}\text { Apakah anda menyukai makanan dengan olahan } \\
\text { ayam? }\end{array}$ & Ya & 21 \\
\hline $\begin{array}{l}\text { Apakah anda pernah melihat kuliner dengan } \\
\text { olahan ayam yang seperti "cheeWings"? }\end{array}$ & Tidak & 6 \\
\hline $\begin{array}{l}\text { Apakah anda mengetahui bahwa mengolah } \\
\text { ayam dengan cara dipanggang lebih baik } \\
\text { daripada digoreng menggunakan minyak? }\end{array}$ & $\mathrm{Ya}$ & 18 \\
\hline $\begin{array}{l}\text { Apakah setelah mendengarkan pemaparan } \\
\text { materi, anda sudah memahami manfaat sayap } \\
\text { ayam? }\end{array}$ & Ya & 20 \\
\hline $\begin{array}{l}\text { Apakah menurut anda, ide tersebut merupakan } \\
\text { ide yang bagus untuk di aplikasikan di } \\
\text { kehidupan sehari-hari? }\end{array}$ & Ya & 21 \\
\hline $\begin{array}{l}\text { Apakah anda tertarik untuk membeli sayap } \\
\text { ayam "cheeWings"? }\end{array}$ & Ya & 20 \\
\hline $\begin{array}{l}\text { Apakah setelah pemaparan tersebut, anda } \\
\text { memiliki minat untuk membuka usaha dengan } \\
\text { ide tersebut? }\end{array}$ & Tidak & 9 \\
\hline \multirow[t]{2}{*}{ Jika iya, apakah alasannya? } & $\begin{array}{c}\text { Rata-rata responden } \\
\text { menjawab tertarik karena } \\
\text { ingin mencoba hal yang } \\
\text { bermanfaat dan } \\
\text { berpeluang mendapat } \\
\text { keuntungan dalam bidang } \\
\text { kuliner }\end{array}$ & \\
\hline & Jumlah & 21 \\
\hline
\end{tabular}

Dari kuesioner pra-pengabdian didapatkan hasil 10 dari 21 orang yang pernah memiliki usaha di bidang kuliner. Namun dari 10 orang yang pernah memiliki usaha kuliner dengan bahan dasar ayam hanya terdapat 2 orang saja. Dari kuesioner tersebut semua responden menyukai makanan dengan olahan ayam, tetapi hanya 11 dari 21 orang yang mengetahui manfaat dari sayap ayam dan hanya 3 orang saja yang tidak tahu bahwa mengolah ayam dengan cara dipanggang lebih baik daripada digoreng menggunakan minyak. Terdapat 6 orang yang belum pernah melihat olahan ayam seperti "cheeWings".

Setelah melakukan pengabdian dan memberi tahu informasi tentang produk dan manfaat dari ayam terutama bagian sayapnya, maka dilihat dari kuesioner setelah pengabdian bahwa 20 dari 21 orang sudah memahami banyaknya manfaat dari sayap ayam. Semua responden juga setuju bahwa ide usaha sate sayap ayam "cheeWing" merupakan 
sebuah ide yang bagus untuk diaplikasikan di kehidupan sehari - hari, dan 20 dari 21 orang tertarik untuk memulai buka usaha dengan ide seperti sate sayap ayam "cheeWings". Beberapa alasan mengapa mereka tertarik untuk membuka usaha dengan ide tersebut adalah menarik, berpeluang mendapatkan keuntungan karena sebagian berpendapat bahwa belum terlalu banyak usaha seperti "cheeWings" dan hampir semua lapisan masyarakat menyukai olahan ayam, selian itu karena terdapat banyak manfaat dari olahan seperti sate sayap ayam "cheeWings".

\section{KESIMPULAN}

Kegiatan PKM cheeWings ini berjalan dengan baik. Para konsumen berkata bahwa produk cheeWings ini memiliki peluang untuk laku di pasaran karena rasanya yang sesuai dengan selera mereka. Kegiatan ini juga bermanfaat untuk meningkatkan minat masyarakat terhadap sayap ayam yang sangat baik bagi kesehatan. cheeWings merupakan terobosan baru makanan ayam dalam bentuk satai dan dengan menggunakan saus yang beraneka macam rasa. Hal ini diharapkan dapat membuat masyarakat untuk mencoba berbagai makanan olahan ayam dengan cara yang unik sehingga masyarakat tidak bosan. Adanya Program Kreativitas Mahasiswa Kewirausahaan (PKM-K) cheeWings ini juga dapat membuka peluang bisnis bagi mahasiswa dan masyarakat umum.

\section{DAFTAR PUSTAKA}

Kuratko, D. F. (2003). Enterpreneurship Education: Emerging Trends and Challenger for the 21st Century. International Journal of Entrepreneurship and Small Business, 11(2), 43-48.

Kurniawati, D. (2013). Pemberdayaan Masyarakat di Bidang Usaha Ekonomi. Jurnal Administrasi Publik, 1(4), 9-14.

Murtidjo, B. A. (2003). Pemotongan dan Penanganan Daging Ayam. Penerbit Kanisius.

Pradata, Y. (2008). Aneka Masakan Dari Ayam (9th ed.). PT. AgroMedia Pustaka.

Pradata, Y., \& Ika Ariestya, R. (2010). 120 Masakan Ayam Terfavorit. TransMedia Pustaka.

Rahmadi, A. C., Maulany, S., \& Ikhsani, M. M. (n.d.). Analisis Faktor-faktor Pengaruh Inovasi Produk yang Berdampak pada Keunggulan Bersaing UKM Makanan dan Minuman di Wilayah Harjamukti Kota Cirebon. Jurnal Logika, 18.

Robbins, S. P. (1994). Teori Organisasi: Struktur, Desain \& Aplikasi. In Terjemahan Yusuf Udaya. Arcan.

Rosmiati, Junias, D. T. S., \& Munawar. (2019). Sikap, Motivasi, dan Minat Berwirausaha Mahasiswa. JKMP (Jurnal Kebijakan Dan Manajemen Publik), 5(2), 183. https://doi.org/10.21070/jkmp.v5i2.1310

Rusdiana, A. (2014). Kewirausahaan Teori dan Praktik. Pustaka Setia.

Rusydi, A., \& Rafida, T. (2016). Pengantar Kewirausahaan. Perdana Publishing.

Saragih, R. (2017). Membangun Usaha Kreatif, Inovatif Dan Bermanfaat Melalui Penerapan Kewirausahaan Sosial. Jurnal Kewirausahaan, 3. 
Shalahuddin, I., Maulana, I., \& Eriyani, T. (2018). Prinsip-prinsip Dasar Kewirausahaan. Deepublish.

Soechan, L. (2014). 70 Resep Yummy Chicken Wing. PT. Gramedia Pustaka Utama.

Sukmadi. (2016). Inovasi \& Kewirausahaan (Paradigma). Humaniora Utama Press.

Susanto, S. (2006). Seri Makanan Favorit: Ayam Goreng Tradisional Indonesia. Gramedia Pustaka Utama.

Suseno, D. (2008). Pengaruh Karakteristik Wirausaha dan Potensi Kewirausahaan Terhadap Keberhasilan Usaha dengan Kebijakan Pembangunan UKM sebagai Moderating. Jurnal Ekonomi Bisnis, 20(1), 23-35. 